\title{
PENGEMBANGAN SOAL PENALARAN MODEL TIMSS PADA MATERI GEOMETRI DAN PENGUKURAN SMP
}

\author{
Adi Pribadi ${ }^{1}$, Somakim ${ }^{2}$, M. Yusup ${ }^{3}$ \\ ${ }^{1}$ Mahasiwa Program Studi Pendidikan Matematika \\ ${ }^{2,3}$ Dosen FKIP - Universitas Sriwijaya \\ E-mail: adipribadikgs@yahoo.co.id
}

\begin{abstract}
ABSTRAK
Penelitian ini bertujuan untuk mengembangkan soal penalaran matematika model TIMSS konten geometri dan pengukuran yang valid baik secara logis dan empiris serta mempunyai efek potensial terhadap peserta didik. Jenis penelitian ini adalah Design Reseacrh tipe Development Studies. Subjek dari penelitian ini adalah peserta didik SMP Negeri 1 Palembang kelas VIII.7 yang berjumlah 26 orang siswa. Proses pene litian ini melalui tahapan Preliminary Evaluation dan Formative Evaluation. Berdasarkan hasil penelitian, diperoleh 5 soal penalaran matematika. Soal-soal tersebut memenuhi karakteristik TIMSS dan memenuhi indikator soal penalaran TIMSS. Dari hasil field test yang dilakukan, diketahui terdapat 17 siswa $(63,3846 \%)$ yang mendapatkan nilai di atas rata-rata, dimana rata-rata nilai siswa yaitu 70,55.
\end{abstract}

Kata-kata Kunci : TIMSS, Development Research, penalaran.

\section{Pendahuluan}

TIMSS (Trends In International Mathematics and Science Study) merupakan seri pengujian berskala internasional yang paling mutakhir yang diselenggarakan di 50 negara untuk mengukur kemajuan dalam pembelajaran Matematika dan Ilmu Pengetahuan Alam (IPA). Tujuan utama TIMSS adalah meningkatkan untuk meningkatkan pengajaran dan pembelajaran matematika dan IPA dengan cara menyediakan data tentang prestasi para siswa dalam kaitannya dengan kurikulum, praktik pengajaran dan lingkungan sekolah yang berbeda beda ( Hayat dan Yusuf, 2011: 245-246).

Pencapaian prestasi Indonesia pada TIMSS 2011 yang diikuti 42 negara, posisi Indonesia berada pada peringkat ke - 38 dengan skor 386 poin. Skor tersebut dibawah rata - rata skor pencapaian matematika internasional yaitu 500 poin (Mullis, dkk., 2012). Di tahun 2015, Indonesia kembali ikut serta dalam TIMSS yang diikuti oleh 50 negara peserta. Pencapaian prestasi matematika Indonesia berada pada peringkat 45 dengan skor 397 poin ( Rahmawati, 2015).

Rendahnya pencapaian prestas Indonesia dalam TIMSS disebabkan oleh beberapa faktor. Salah satunya adalah soal - soal yang diberikan kepada peserta 
Histogram: Jurnal Pendidikan Matematika, Volume 1 Nomor 2, September 2017, pp 115-128

didik di kompetisi internasional tersebut berbeda dengan soal - soal yang biasa diberikan kepada kebanyakan peserta didik di

Indonesia (Siti Fatimah, 2012). Pendapat ini juga didukung oleh paparan Kemendikbud tentang Implementasi Kurikulum 2013, yaitu ada materi yang diujikan di TIMSS yang belum diajarkan kepada peserta didik di Indonesia. Gambar 1 menunjukkan materi apa saja yang belum diajarkan tersebut kepada peserta didik di indonesia.

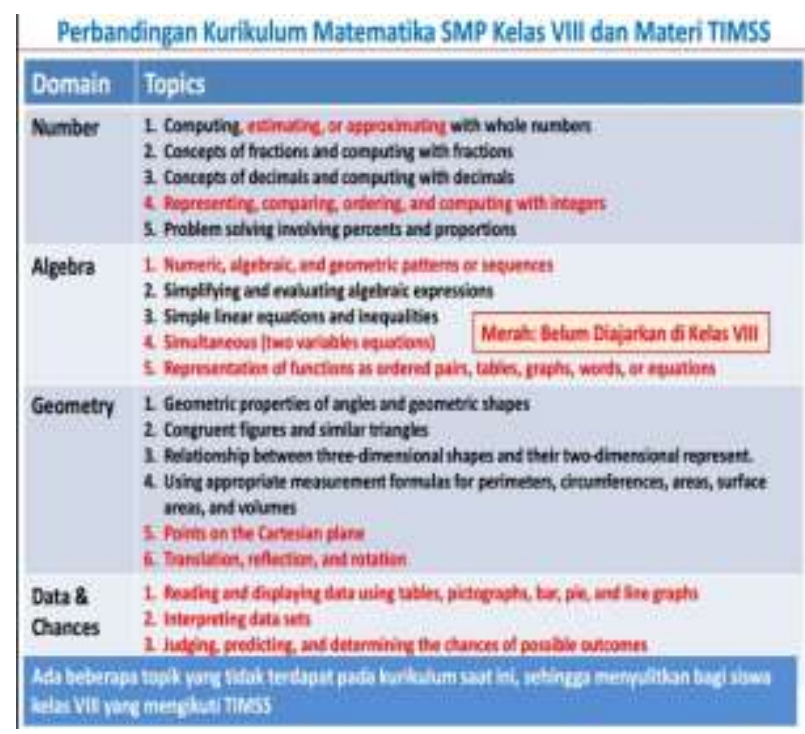

Gambar 1. Materi yang di ujikan di TIMSS

Selain itu berdasarkan hasil TIMSS 2015, Indonesia juga lemah dalam aspek konten Geometri dan aspek kognitif pada kemampuan penalaran. Hasil pencapaian siswa Indonesia dalam dua aspek tersebut disajikan dalam gambar 2.

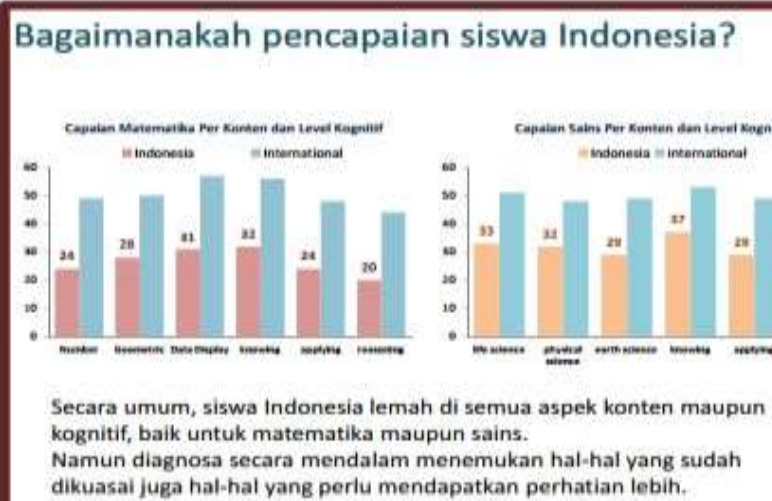

Secara umum, siswa Indonesia lemah di semua aspek konten maupun kognitif, baik untuk matematika maupun sains.

Namun diagnosa secara mendalam menemukan hal-hal yang sudah dikuasai juga hal-hal yang perlu mendapatkan perhatian lebih.

Gambar 2. Pencapaian Prestasi Indonesia 
Dari gambar 2 dapat dilihat bahwa pencapaian kemampuan penalaran siswa Indonesia mempunyai persentase yang paling rendah dan kemampuan di konten geometri menempati urutan kedua dari tiga aspek kognitif yang diujikan.

\section{METODE PENELITIAN}

\section{A. Jenis Penelitian}

Penelitian ini merupakan penelitian pengembangan atau development research tipe formative evaluation (Tessmer,1993). Penelitian ini bertujuan untuk mengembangkan soal-soal penalaran matematika model TIMSS konten Geometri dan Pengukuran untuk mengetahui kemampuan penalaran matematis siswa SMP yang valid dan praktis. Subjek dari penelitian ini adalah siswa SMP Negeri 1 Palembang tahun pelajaran 2015/2016 yang berjumlah 26 orang siswa. Penelitian ini dilaksanakan pada semester genap tahun pelajaran 2015/2016.

Penelitian ini terdiri dari dua tahap, yaitu tahap preliminary dan tahap formative evaluation yang meliputi self evaluation, prototyping (expert reviews, one to one (low resistance to revision), dan small group), serta field test (high resistance to revision) (Tessmer, 1993)

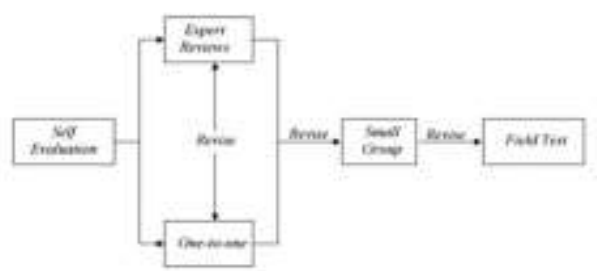

Gambar 3. Alur Desain Formative Research ～(Tessmer,1993 ; Zulkardi, 2006)

Pada bagian ini dijelaskan pendekatan dan jenis penelitian, subjek penelitian dan partisipan

\section{B. Metode Pengumpulan Data}

Pada penelitian ini, pengembangan soal dilakukan dengan mengacu pada alur desain pada gambar 3. Pada tahap self evaluation peneliti mengevaluasi sendiri soal yang sudah dibuat sebelumnya pada tahap persiapan dan desain. Dari tahapan tersebut soal dievaluasi dan didapatkan prototype 1 . Kemudian prototype 1 ini dibawa ke tahap selanjutnya yaitu expert review dan one-to- one. Peneliti meminta bantuan 4 orang expert yaitu :

1. Dr. Ely Susanti, M.Pd.

2. Puji Astuti, S.Pd.,M.Sc. 
3. Amrina Rizta, M.Pd.

4. Nurjannaha, M.Pd.

Pada proses one-to-one peneliti meminta bantuan 3 orang siswa dari SMP N 1 yang direkomendasikan oleh guru mata pelajaran matematika dengan ketentuan siswa yang dipilih memiliki kemampuan tinggi, sedang dan rendah.

Hasil atau temuan yang diperoleh pada expert review dan one-to-one dijadikan bahan untuk merevisi prototype I sehingga menghasilkan prototype II. Prototype II inilah yang akan diujicobakan pada small group yang terdiri dari 6 orang siswa, masing- masing 2 orang dengan kemampuan tinggi, 2 orang dengan kemampuan sedang, dan 2 orang dengan kemampuan rendah. Secara bersama-sama keenam siswa tersebut diminta untuk menyelesaikan soal dari prototype II. Selain itu, siswa juga dimintai komentar terhadap soal yang diberikan melalui lembar komentar siswa.

Sebelum soal diujicobakan ke tahap field test, peneliti melakukan uji coba untuk menunjukkan soal mana saja yang dianggap valid secara empiris. Dari hasil uji coba tersebut dilakukan analisis butir soal untuk menguji validitas butir soal dan reliabilitas soal, tingkat kesukaran dan indeks pembeda. Hasil uji coba ini dianalisis dan dibahas sedemikian rupa sehigga menghasilkan saran-saran untuk merevisi prototype II. Hasil revisi soal berdasarkan saran dan komentar siswa pada small group dan hasil analisi butir soal dinamakan prototype III.

Prototype III inilah yang di ujicobakan ke subjek penelitian, yaitu siswa kelas VIII SMP Negeri 1 Palembang yang berjumlah 26 orang. Hasil dari field test tersebut dilakukan perhitungan terhadap skor dari setiap siswa dan digunakan sebagai dasar penelitian terhadap kemampuan penalaran matematis siswa.

\section{Metode Analisis Data}

1. Analisis Walkthrough

Berdasarkan hasil walkthrough yang dilakukan pada tahap expert review oleh pakar yang memberikan masukan terhadap kejelasan soal dan kesesuaian soal dengan kemampuan yang akan di kembangkan, maka peneliti melakukan analisis berdasarkan komentar dan saran dari pakar secara deskriptif. Hal ini menjadi dasar untuk merevisi soal yang dibuat sehingga dapat menghasilkan soal yang valid secara deskrptif. 
2. Analisis Dokumen

Pada tahap expert review analisis dokumen digunakan untuk menganalisis kevalidan. Sedangkan pada tahap one-to- one dan small group digunakan untuk menganalisis kepraktisan soal. Pada tahap field test, analisis dokumen digunakan untuk melihat efek potensial.

3. Analisis Wawancara

Analisis data dari hasil wawancara dilakukan untuk melihat respon siswa terhadap soal dan digunakan untuk memperbaiki prototype.

4. Analsis Data Hasil Tes Prototype

Analisi data hasil tes prototype pada tahap field test digunakan untuk mengetahui efek potensial dari soal-soal yang dikembangkan dalam menggali kemampuan penalaran matematis siswa. Skor yang didapat oleh siswa dari hasil tes prototype merupakan jumlah skor yang mereka dapat saat menyelesaikan soal-soal penalaran matematika model TIMSS. Kriteria dalam penskoran kemampuan penalaran peserta didik dikembangkan dari kriteria atau indikator kemampuan penalaran TIMSS.

Hasil jawaban dari siswa diberi skor dengan berpedoman pada tabel 3.3. berdasarkan pedoman penskoran nilai tes tersebut, selanjutnya skor yang diperoleh siswa diberikan penilaian menurut rumus:

$$
\text { Nilai siswa }=\frac{\text { jumlah skor yang di peroleh }}{\text { jumlah skor maksimal }} \times 100
$$

Selanjutnya nilai siswa dianalisis untuk menentukan tingkat kemampuannya dalam penalaran matematis yang dikategorikan dalam tabel 3.4 berikut.

Tabel 1 Kategori kemampuan penalaran matematis.

\begin{tabular}{cc}
\hline Nilai & $\begin{array}{c}\text { Tingkat kemampuan } \\
\text { penalaran matematis }\end{array}$ \\
\hline $81-100$ & Sangat baik \\
\hline $66-80$ & Baik \\
\hline $51-65$ & Cukup \\
\hline $0-50$ & Kurang \\
\hline
\end{tabular}

(Sumber: Kurikulum, Tahun: 2013) 
5. Uji Validitas dan Reliabilitas

Untuk mengukur validitas dari alat ukur digunakan teknik korelasi product momen yang dikemukakan oleh Pearson. Rumus korelasi product momen dengan simpangan:

$$
r_{x y}=\frac{\sum x y}{\sqrt{\left(\sum x^{2}\right)\left(\sum y^{2}\right)}}
$$

Dimana:

- $r_{x y}$ adalah koefisien korelasi antara dua variabel $\mathrm{X}$ dan variabel $\mathrm{Y}$, dua variable yang dikorelasikan $(x=X-\bar{X}$ dan $y=Y-\bar{Y})$

- $\sum x y$ adalah jumlah perkalian $\mathrm{x}$ dan $\mathrm{y}$

- $x^{2}$ adalah kuadrat dari $\mathrm{x}$

- $y^{2}$ adalah kuadrat dari y

Keputusan validitas butir soal ditentukan dengan membandingkan rhitung dengan $r_{\text {tabel. }}$ Butir soal dikatakan valid apabila $r_{\text {hitung }}>r_{\text {tabel }}$ dan tidak valid apabila $\mathrm{r}_{\text {hitung }}<\mathrm{r}_{\text {tabel. }}$. Harga $\mathrm{r}_{\text {tabel }}$ diperoleh dari tabel distribusi $\mathrm{r}$ dengan $a=$ 0.05 dan derajat kebebasan $d k=n-2$.

Rumus yang digunakan untuk mencari reliabilitas yaitu Rumus Alpha berikut:

$$
\mathrm{r} 11=\left(\frac{n}{n-1}\right)\left(1-\frac{\sum \sigma_{t}^{2}}{\sigma_{t}^{2}}\right)
$$

Dimana:

$\mathrm{r}_{11}=$ reliabilitas yang dicari

$\sum \sigma_{t}^{2}=$ jumlah variansi skor tiap-tiap item

$\sigma_{\mathrm{t}}^{2} \quad=$ varians total

$\mathrm{n} \quad=$ banyak subjek yang di tes

Keputusan reliabilitas butir soal ditentukan dengan membandingkan $\mathbf{r}_{\text {hitung }}$ dengan $r_{\text {tabel. }}$ Butir soal dikatakan valid apabila $r_{\text {hitung }}>r_{\text {tabel }}$ dan tidak valid apabila $\mathrm{r}_{\text {hitung }}<\mathrm{r}_{\text {tabel. }}$. Harga rtabel diperoleh dari tabel distribusi $\mathrm{r}$ dengan $a=$ 0.05 dan derajat kebebasan $d k=n-2$.

\section{HASIL DAN PEMBAHASAN}

Pada Penelitian ini menghasilkan sebanyak lima soal dari 7 buah soal penalaran model TIMSS pada materi geometri dan pengukuran yang valid. Pengembangan soal model TIMSS ini dilakukan pada tingkat SMP. Tahapan- tahapan dalam penelitian ini 
adalah tahap preliminary (analisis dan pendesainan) dan tahap formative evaluation (self evaluation dan prototyping).

\section{A. Expert reviews}

Pada tahap ini, prototype yang terdiri dari kisi-kisi soal, kartu soal, rubrik penskoran dan soal penalaran model TIMSS divalidasi oleh empat orang pakar yang sudah berpengalaman dalam pendidikan matematika. Tujuannya adalah untuk mendapatkan desain soal yang valid secara kualitatif.

\section{B. One-to-one}

Tahap one-to-one dilakukan pada peserta didik kelas VIII.8. Prototype 1 diujicobakan kepada tiga orang peserta didik dengan kemampuan yang berbeda. Peserta didik yang berkemampuan rendah (M.J.P), peserta didik berkemampuan sedang (K.M.Z), dan peserta didik berkemampuan tinggi (A). Setelah melalui tahap expart dan one two soal yang di buat revisi.

Namun sebelum dilanjutkan pada tahap small group, soal yang dibuat diuji cobakan dulu di satu kelas untuk menghitung validitas dan reliabilitas dari soal. Hasilnya disajikan dalam tabel 2.

Tabel 2. Hasil Analisis Soal

\begin{tabular}{cccc}
\hline No & $\mathbf{R}$ & $\mathbf{R}$ tabel$(\mathbf{0 , 4 6 8})$ & Kesimpulan \\
\hline $\mathbf{1}$ & 0,263 & $\mathrm{r}_{\text {hitung }} \leq \mathrm{r}_{\text {tabel }}$ & Tidak valid \\
\hline $\mathbf{2}$ & 0,834 & $\mathrm{r}_{\text {hitung }} \geq \mathrm{r}_{\text {tabel }}$ & valid \\
\hline $\mathbf{3}$ & 0,770 & $\mathrm{r}_{\text {hitung }} \geq \mathrm{r}_{\text {tabel }}$ & valid \\
\hline $\mathbf{4}$ & 0,253 & $\mathrm{r}_{\text {hitung }} \leq \mathrm{r}_{\text {tabel }}$ & Tidak valid \\
\hline $\mathbf{5}$ & 0,629 & $\mathrm{r}_{\text {hitung }} \geq \mathrm{r}_{\text {tabel }}$ & Valid \\
\hline $\mathbf{6}$ & 0,568 & $\mathrm{r}_{\text {hitung }} \geq \mathrm{r}_{\text {tabel }}$ & Valid \\
\hline $\mathbf{7}$ & 0,625 & $\mathrm{r}_{\text {hitung }} \geq \mathrm{r}_{\text {tabel }}$ & valid \\
\hline
\end{tabular}

(Sumber: Data Primer, Tahun: 2016)

\section{Small Group}

Tahap ini dilakukan pada tanggal 23 Maret 2016 di kelas VIII.8 SMP Negeri 1 Palembang. Waktu yang digunakan untuk uji coba adalah selama dua jam pelajaran. Pada tahap ini hasil revisi dari prototype 1 ( prototype 2 ) yang telah valid dan memiliki reliabilitas yang tinggi diujicobakan kepada enam orang peserta didik. 
Histogram: Jurnal Pendidikan Matematika, Volume 1 Nomor 2, September 2017, pp 115-128

Enam orang peserta didik tersebut terdiri dari 2 orang peserta didik dengan kemampuan tinggi (A.F. dan F.S.), 2 orang peserta didik dengan kemampuan sedang ( K. dan M.F. ), dan 2 orang dengan kemampuan rendah (M.R. dan O.M.).

\section{Field Test}

Pada tahap ini, prototye 3 diujicobakan pada tanggal 30 Maret 2016 kepada peserta didik keals VIII.7 SMP Negeri 1 Palembang yang berjumlah 26 orang peserta didik. Peserta didik mengerjakan soal tes selama 2 jam pelajaran. Setelah itu peneliti juga menghitung persentase kemampuan peserta didik menggunakan pedoman penskoran kemampuan penalaran. Hasil dari penghitungan tersebut disajikan dalam tabel 3 .

Tabel 3. Hasil Kemampuan Penalaran

\begin{tabular}{ccc}
\hline Interval & Frekuensi & Presentase(\%) \\
\hline $\mathbf{8 1 - 1 0 0}$ & 8 & 30,76 \\
\hline $\mathbf{6 6 - 8 0}$ & 5 & 19,23 \\
\hline $\mathbf{5 1 - 6 5}$ & 11 & 42,30 \\
\hline $\mathbf{0 - 5 0}$ & 2 & 7,71 \\
\hline Jumlah & 26 & 100 \\
\hline
\end{tabular}

(Sumber: Data Primer, Tahun: 2016)

\section{E. Pembahasan}

Proses pengembangan instrumen soal matematika model TIMSS konten geometri dan pengukuran kelas VIII melalui dua tahapan penting yaitu tahap preliminary evaluation dan tahap formative evaluation. Pada tahap preliminary peneliti melakukan analisis terhadap peserta didik, kurikulum, buku teks, dan soal-soal TIMSS konten Geometri dan Pengukuran serta melakukan pendesainan soal yang dimulai dari kisikisi dan kartu soal. Setelah itu peneliti melanjutkan ke tahap formative evaluation untuk melihat apakah soal yang dikembangkan valid dan reliabel. Peneliti mengembangan sebanyak 7 butir soal TIMSS yang mengukur kemampuan penalaran peserta didik. Soalsoal tersebut dievaluasi dan direvisi dengan arahan pembimbing pada tahap self evaluation. Sehingga didapatlah prototype 1 yang selanjutnya akan divalidasi ke tahap expert dan one-to-one. Pada tahap expert, soal yang dikembangkan dilihat kelebihan dan kelemahannya. Pada tahap ini, peneliti duduk bersama dengan expert saat memeriksa instrumen yang di buat. Pada tahap ini, soal akan dilihat apakah sudah memenuhi 
kriteria valid secara konten, konstruk dan bahasa. Pada penelitian kali ini, peniliti melaksanakan proses expert terlebih dahulu. Peneliti memilih empat orang expert yang akan memvalidasi prototye 1 . Setelah selesai dengan tahap expert peneliti merevisi sesuai komentar dan saran dari expert. Peneliti mencatat komentar dan saran yang diberikan oleh expert.

Selanjutya peneliti melanjutkan ke tahap one-to-one. Pada tahap ini peneliti memilih 3 orang peserta didik dengan kemampuan yang berbeda. Satu orang dengan kemampuan rendah, satu orang dengan kemampuan sedang dan satu orang dengan kemampuan tinggi. Mereka diminta untuk mengerjakan soal yang dikembangkan oleh peneliti mulai dari konten, konstruk dan bahasa yang digunakan dalam soal tersebut. Pada tahap ini setiap subjek penelitian diminta untuk memvalidasi tujuh butir soal penalaran model TIMSS. Dari hasil validasi tersebut siswa dengan kemampuan rendah mengalami kesulitan dalam memahami beberapa soal, yaitu soal nomor 2, 4, 5, 6, dan 7. Ini sesuai dengan pendapat yang dikemukakan oleh Hayat dan Yusuf (2011) yang menyatakan bahwa soal TIMSS adalah soal yang memiliki kompleksitas yang tinggi. Sehingga peserta didik yang memiliki kemampuan yang rendah mengalami kesulitan dalam memahai soal dibandingkan dengan siswa yang memiliki kemampuan sedang dan tinggi.

Tahap one-to-one ini sangat bermanfaat untuk melengkapi informasi berdasarkan dari sudut pandang peserta didik. Pada tahap ini peneliti lebih mempunyai banyak waktu untuk bicara kepada peserta didik untuk mengetahui mengapa mereka mengalami kebingungan atau kesulitan dalam memahami beberapa aspek yang ada pada instrumen penelitian. Setelah proses ini selesai, peneliti melakukan revisi terhadap instrumen.

Setelah melalui tahapan tersebut maka didapatkanlah konten soal sudah sesuai dengan karakter soal TIMSS, soal yang dikembangkan telah sesuai untuk mengukur kemampuan penalaran peserta didik berdasarkan karakteristik domain kognitif TIMSS dan bahasa yang digunakan tidak menyebabkan penafsiran ganda atau ambiguitas saat dikerjakan oleh peserta didik sehingga soal dapat dipahami dengan baik. Dari hasil tahap expert dan one-to-one, soal yang dikembangkan direvisi sesuai dengan komentar dan saran yang diberikan. Berdasarkan hasil penelitian dari dua tahap ini, dapat disimpulkan bahwa soal yang dikembangkan sudah memenuhi kriteria valid secara logis, sehingga didapatkan prototype 2 dari tahap ini. 
Histogram: Jurnal Pendidikan Matematika, Volume 1 Nomor 2, September 2017, pp 115-128

Kemudian peneliti melakukan tahap validasi secara empiris. Untuk tahap ini, peneliti melakukan pengambilan data pada kelas yang berbeda dengan kelas yang akan dijadikan sebagai kelas pengambilan data untuk tahap field test. Peneliti mengambil data di kelas VIII.6 yang berjumlah 18 orang. Mereka diminta untuk mengerjakan soal dalam waktu dua jam pelajaran. Untuk menganalisis data digunakan rumus gunakan korelasi product moment dan uji reliabilitas dengan korelasi biserial. Peneliti mendapatkan hasil yaitu soal dikembangkan memenuhi juga syarat validitas dan reliabilitas secara empiris, artinya soal yang dikembangkan mempunyai tingkat kepercayaan yang tinggi dan dapat digunakan dimanapun sebagai instrumen tes.

Dari aspek keterbacaan soal,peneliti melakukan tahapan selanjutnya yaitu tahap small group. Pada tahap ini, peneliti melakukan uji coba prototype 2 yang sudah valid dan reliabel kepada enam orang peserta didik yang dibagi menjadi dua orang dengan kemampuan rendah, dua orang dengan kemampuan sedang, dan dua orang dengan kemampuan tinggi. Dari hasil tahap small group didapat bahwa sebagian besar peserta didik sudah mampu untuk memahami soal dengan baik dan dapat mengerjakan soal dengan benar. Namun ada beberapa peserta didik yang masih merasa kesulitan dalam mengerjakan soal. Kendala mereka yang peneliti temukan dari analisis lembar jawaban adalah kesalahan dalam menentukan strategi menyelesaikan soal dan beberapa kesalahan dalam menghitung. Namun dari analisis lembar jawaban peserta didik sudah muncul indikator - indikator kemampuan penalaran yang susuai dengan indikator penalaran model TIMSS dalam framework TIMSS 2015 Indikator penalaran yang muncul juga sesuai dengan pendapat yang dikemukakan oleh Sumarmo (2003) yang menyatakan bahwa kemampuan penalaran muncul dalam bentuk menarik kesimpulan, menggunakan fakta, sifat- sifat, model dan hubungan, menggeneralisasi dan membuat argumen yang valid. Indikator tersebut muncul pada jawaban dari subjek penelitian yaitu O.M., A.F. dan K. Langkah - langkah tersebut sangatlah penting pada proses penalaran matematis. Hal ini di dukung oleh pendapat dari Shadiq (2014) yang menyatakan bahwa penalaran adalah proses atau aktivitas berfikir dalam membuat pernyataan yang benar berdasarkan kebenaran yang ada sebelumnya. Dari tahapan ini juga didapatkan komentar dari peserta didik terhadap prototype 2 yang peneliti gunakan untuk merevisi kembali soal sehingga didapatkanlah prototype 3 . 
Setelah didapatkan prototype 3 yang valid dan reliabel, peneliti melanjutkan proses penelitian ke tahap field test untuk melihat hasil tes peserta didik menggunakan soal yang sudah dikembangkan. Tahap ini dilakukan di kelas VIII.7 yang berjumlah 26 peserta didik. Pada tabel 4.4 dapat kita lihat bahwa sebanyak 17 orang peserta didik mendapatkan nilai diatas rata-rata $(63,3846 \%)$. Dimana rata-rata dari nilai field test peserta didik adalah 70,55.

Dari hasil field test yang telah dilakukan dapat dinyatakan bahwa soal penalaran matematika model TIMSS konten Geometri dan Pengukuran yang dikembangkan peneliti dapat digunakan di kelas VIII SMP Negeri 1 Palembang, sehingga dapat disimpulkan bahwa:

1. Soal yang dikembangkan sesuai dengan framework TIMSS dimana setiap satu soal mengukur satu domain konten dan satu domain kognitif. Pada hasil analisis lembar jawaban field test peserta didik dapat dilihat bahwa indikator kemampuan kognitif yang hendak diukur muncul.

2. Soal berbentuk uraian singkat yang valid dan praktis.

3. Soal dapat dikerjakan dalam waktu yang wajar, yaitu 2 jam pelajaran.

4. Bahasa dan konteks yang digunakan mudah dimengerti oleh peserta didik.

5. Soal terbatas dari faktor bias karena tidak ada konteks kedaerahan dan diskriminasi gender.

6. Bahasa yang digunakan mudah diterjemahkan kedalam bahasa lain karena pada soal tidak terdapat idiom atau bahasa daerah tertentu yang akan menyulitkan proses alih bahasa.

Secara keseluruhan peneliti masih menemukan peserta didik yang mengalami kesulitan dalam mengerjakan soal model TIMSS ini. Hal ini mungkin saja dikarenakan mereka belum pernah berlatih untuk menjawab soal dengan tipe seperti ini. Kebanyakan peserta didik kesulitan dalam memahami soal dan melihat keterkaitan informasi yang ada di dalam soal dan gambar pada soal. Namun tidak sedikit pula peserta didik yang dapat memahami soal dengan baik dan dapat mengerjakan soal dengan rinci dan berurutan sampai mendapatkan hasil akhir yang benar. 49,99\% peserta didik memiliki nilai pada kemampuan penalaran yang berada pada kategori kemampuan penalaran yang baik. Hal ini juga sejalan dengan hasil penelitian yang dilakukan oleh Amrina (2013) yang menyatakan bahwa 59,26\% peserta didik mendapatkan nilai kemampuan penalaran diatas rata - rata. Begitu pula dengan penelitian Rahmawati 
(2016) yang menyatakan bahwa 70,94 \% peserta didik memiliki kemampuan penalaran yang tergolong baik.

\section{KESIMPULAN DAN SARAN}

Pada penelitian ini, soal penalaran matematika model TIMSS dikembangkan melalui tahapan evaluasi dari Tessmer, mulai dari tahap preliminary hingga tahap formative evaluation. Proses tersebut dilakukan untuk mengetahui karakteristik soal penalaran model TIMSS yang dikembangkan. Pada penelitian ini peneliti mengembangkan 7 buah soal dan menghasilkan 5 butir soal penalaran matematika model TIMSS yang valid dan praktis. Indikator - indikator soal penalaran model TIMSS sudah mulai terlihat berdasarkan analisis lembar jawaban peserta didik, walaupun belum semua indikator penalaran tersebut muncul pada semua jawaban mereka. Masih ada indikator yang sering terlewatkan oleh mereka seperti mereka harus membuat kesimpulan dan memeriksa kembali jawaban.

Dari analisis tersebut pada beberapa telah muncul semua indikator kemampuan penalaran yang diinginkan. Mereka dapat menuliskan jawaban mereka dengan terstruktur dan benar. Hal ini menunjukkan bahwa soal yang dikembangkan menjalankan fungsinya dengan baik sebagai alat ukur kemampuan penalaran yang valid dan praktis. Hal ini juga dilihat dari skor pencapaian hasil field test yang menunjukkan bahwa $63,3864 \%$ peserta didik (17 orang) mendapatkan nilai diatas 70,55 dan dari aspek kemampuan penalaran hampir 50\% (13 orang) peserta didik mempunyai kemampuan penalaran yang tergolong baik dan sangat baik.

\section{DAFTAR PUSTAKA}

Akker, J.V. (1999). Principles and Methods of Development Research. In J. Van den Akker, R.M. Branch, K. Gustafson, N. Nieveen and Tj. Plomp. Design Approaches and Tools in Education and Training (hlm1-14). Dordrecht: Springer.

Aminuddin. (2012). Pengembangan Soal Matematika Model PISA Pada Konten Shape and Space untuk Mengetahui Kemampuan Koneksi Matematis Siswa. Tesis. Palembang: Program Magister Pendidikan Matematika PPS Universitas Sriwijaya.

Arikunto, S. (2013). Dasar-Dasar Evaluasi Pendidikan Edisi 2. Jakarta: Bumi Aksara. 
Brodie, K. (2010). Teaching Mathematical Reasoning in Secondary School Classroom. New York: Springer. Diakses Pada Tanggal 9 Maret 2017 di http://link.springer.com/book/10.1007/978-0-387-09742-8/.

Djaali \& Mujiono, P. (2008).Pengukuran dalam Bidang Pendidikan. Jakarta: Grasindo.

Emiliya, D., Darmawijoyo, \& Putri, R.I.I. (2010). Pengembangan Soal-Soal Open Ended Materi Lingkaran Untuk Meningkatkan Penalaran Matematika Siswa Kelas VIII Sekolah Menengah Pertama Negeri 10 Palembang. Journal Pendidikan Matematika Program Pasca Sarjana Universitas Sriwijaya Volume 4. No. 2 Desember 2010.

Fatimah, S. (2012). Pengembangan Soal Matematika Model TIMSS Konten Geometri untuk Mengetahui Kemampuan Pemecahan Masalah Siswa SMP. Tesis. Program Magister Pendidikan Matematika PPS Universitas Sriwijaya.

Hamzah, A. (2014). Evaluasi Pembelajaran Matematika. Jakarta: Rajawali Pers.

Hayat, B., \& Yusuf, S. (2011). Benchmark Internasional Mutu Pendidikan. Jakarta: Bumi Aksara.

Jurnaidi \& Zulkardi. (2014).Pengembangan Soal Model PISA Pada Konten Change and Relationship untuk Mengetahui Kemampuan Penalaran Matematika Siswa Sekolah Menengah Pertama. Journal Pendidikan Matematika Program Pascasarjana Universitas Sriwijaya Vol. 8 No. 12014.

Kemendikbud. (2013). Permendikbud No. 66 Tahun 2013 Tentang Standar Penilaian Pendidikan. Jakarta: Kemendikbud.

Kemendikbud. (2013). Permendikbud No. 68 Tahun 2013 Tentang Kompetensi Dasar dan Kurikulum SMP-MTs. Jakarta: Kemendikbud.

Mullis, I.V.S., Martin, M.O., Foy, P., \& Arora, A. (2012). TIMSS2011 International Result in Mathematics. TIMSS and PIRLS International Study Center, Lynch School of Eduction, Boston College, Chestnut Hill, MA, USA and IEA.

Napitupulu, E. (2008). Peran Penalaran dalam Pemecahan Masalah Matematika. Disajikan dalam Prosiding Seminar Nasional Matematika dan Pendidikan Matematika, 28 November 2008, Yogyakarta.

NCTM. (2000). Principles and Standards for School Mathematics. Reston, V.A: Author. 
Histogram: Jurnal Pendidikan Matematika, Volume 1 Nomor 2, September 2017, pp 115-128

Rahmawati, R.D. (2016). Hasil TIMSS 2015 Diagnosa Hasil untuk Perbaikan Mutu dan Peningkatan Capaian. Diakses pada tanggal 07 Maret 2017 di www.puspendik.kemendikbu d.go.id.

Rahmawati, R.D. (2016). Pengembangan Soal - Soal Berdasarkan Taksonomi Trends in International Mathematics and Science Study (TIMSS) Pada Bidang Aljabar.

Shadiq, F. (2014). Pembelajaran Matematika Cara Meningkatkan kemampuan Berpikir Siswa. Yogyakarta: Graha Ilmu.

Zulkardi, \& Putri,R.I. (2006). Mendesain Sendiri Soal Kontekstual Matematika. Disajikan dalam Prosiding KNKM13, Semarang.

Soemarmo, U., \& Hendriana, H. (2014). Penilaian Pembelajaran Matematika. Bandung: PT. Refika Aditama.

Sudijono, A. (2015). Pengantar Evaluasi Pendidikan. Jakarta: Rajawali Pers.

Mullis, I.V.S., \& Martin, M.O. (2013). TIMSS 2010 Assesment Framework. TIMSS and PIRLS International Study Center, Lynch School of Eduction, Boston College and IEA.

Rizta, A. (2013). Pengembangan Soal Pilihan Ganda Model TIMSS untuk Mengukur Kemampuan Penalaran Matematis Siswa SMP. Tesis. Palembang: Program Magister Pendidikan Matematika PPS Universitas Sriwijaya.

Tessmer, M. (1993). Planing and Conducting Formative Evaluation. London: Kogan Page.

Wahyudi, T. (2015). Pengembangan Soal Matematika Tipe TIMSS Menggunakan Budaya Lampung Tingkat SMP. Tesis. Palembang: Program Magister Pendidikan Matematika PPS Universitas Sriwijaya. 